CZASOPISMO INŻYNIERII LĄDOWEJ, ŚRODOWISKA I ARCHITEKTURY JOURNAL OF CIVIL ENGINEERING, ENVIRONMENT AND ARCHITECTURE

JCEEA, t. XXXIV, z. 64 (1/17), styczeń-marzec 2017, s. 15-22, DOI:10.7862/rb.2017.2

Michał MUSIAŁ ${ }^{1}$

\title{
ZASTOSOWANIA MATERIAŁÓW PCM WE WSPÓŁPRACY Z PRZEGRODAMI TRANSPARENTNYMI
}

\begin{abstract}
Poniższy artykuł stanowi przegląd wiedzy na temat przykładów wykorzystania materiałów PCM (ang. phase change materials) w celu modyfikacji transparentnych przegród budowlanych.

W związku $\mathrm{z}$ powstawaniem nowych sposobów wykorzystywania PCM w przegrodach przezroczystych, konieczne jest usystematyzowanie wiedzy w tym zakresie. W artykule przedstawiono zasadnicze właściwości substancji zmiennofazowych uzasadniające ich coraz częstsze stosowanie w budownictwie, występujące na runku budowlanym produkty modyfikowane w/w substancjami, jak i wyniki badań prowadzonych nad nowymi, dotychczas nie stosowanymi w budownictwie zastosowaniami PCM-ów. Autor odnosi się do prac, w których opisano różne możliwości stosowania w/w materiałów w celu zwiększenia, między innymi, bezwładności cieplnej przegród budowlanych. Przedstawione zostały zastosowania PCMów zarówno w przegrodach nieprzeziernych i przeziernych, z przewagą ostatniej $\mathrm{z}$ wymienionych grup. $\mathrm{W}$ pracach przedstawiających zalety $\mathrm{i}$ wady modyfikowania przegród transparentnych materiałami PCM autorzy odnoszą się przede wszystkim do zwiększenia bezwładności cieplnej przegrody, a co za tym idzie zmniejszenia wrażliwości przeszkleń na zmianę warunków atmosferycznych i natężenia promieniowania słonecznego.

Autor zwraca uwagę na czynniki takie jak zakres i wartość temperatury przemiany fazowej, charakter substancji, powtarzalność cykli topnienie- krzepnięcie, zmiany objętości związanych ze zmianą stanu skupienia, przewodność cieplną substancji. Dodatkowo w zależności od chęci ograniczenia przegrzewania lub przechłodzenia pomieszczeń znaczenie ma również sposób oraz miejsce aplikacji PCM-ów. Powyższe czynniki mają znaczący wpływ na skuteczność wymienionych w artykule rozwiązaniach.

Przeważająca ilość prac naukowych opisujących wykorzystanie substancji zmiennofazowych w budownictwie odnosi się do nieprzezroczystych przegród budowlanych, co świadczy o niekonwencjonalnym ujęciu niniejszej pracy.
\end{abstract}

Słowa kluczowe: substancje zmiennofazowe, przegrody przezroczyste, modyfikacja przegród budowlanych

\footnotetext{
${ }^{1}$ Michał Musiał, Politechnika Rzeszowska, 35-959 Rzeszow, al. Powstańców Warszawy 12, tel. 178651005, email: mmusial@prz.edu.pl
} 


\section{Wprowadzenie}

$\mathrm{W}$ dobie dążenia do zmniejszenia kosztów związanych z utrzymaniem w budynkach pożądanego zakresu temperatury powietrza coraz częściej wykorzystuje się energię ze źródeł odnawialnych.

Dodatkowym argumentem świadczącym o potrzebie zwiększenia produkcji ilości energii ze źródeł odnawialnych jest podpisana, między innymi przez Polskę, dyrektywa 2009/28/WE, na mocy której kraje członkowskie Unii Europejskiej do 2020 roku powinny osiągnąć dwudziestoprocentowy udział energii ze źródeł odnawialnych. Jedną z możliwości obniżenia kosztów związanych z ogrzewaniem i chłodzeniem pomieszczeń jest modyfikacja materiałami PCM przegród przezroczystych.

Substancje zmiennofazowe to związki chemiczne lub ich mieszaniny, które posiadają wysokie ciepło przemiany fazowej (topnienie-krzepnięcie). W zależności od charakteru związków ciepła przemian fazowych mogą wynosić $100-190 \mathrm{~kJ} / \mathrm{kg}$ dla związków organicznych oraz 100-280kJ/kg dla związków nieorganicznych [1].

Wykorzystanie w/w związków przy modernizacji przegród transparentnych skutkuje zwiększeniem bezwładności cieplnej przegrody, a co za tym idzie zmniejszeniem wrażliwości przegród transparentnych na nagłe zmiany natężenia promieniowania słonecznego i temperatury powietrza zewnętrznego.

Najczęściej podawanymi właściwościami, charakteryzującymi PCMy wykorzystywane w budownictwie są:

- zdolność do akumulacji ciepła (zależy od ciepła przemiany fazowej związku od $100-280 \mathrm{~kJ} / \mathrm{kg}$ ),

- przewodność cieplna substancji $(\lambda=0,10-0,30 \mathrm{~W} / \mathrm{m} \mathrm{K})$,

- zachowanie substancji w warunkach przegrzania i przechłodzenia,

- zakres oraz wartość temperatury, w których dochodzi do przemiany fazowej,

- stabilność związku przy wielu cyklach przemiany fazowej.

Przedstawione wyżej parametry szerzej zostały opisane w [2].

Użycie substancji zmiennofazowych $\mathrm{w}$ konstrukcji dowolnej przegrody powoduje zarówno zwiększenie jej akumulacyjności cieplnej, jak i przesunięcie fazowe zmian temperatury przegrody w stosunku do zmian temperatury powietrza na zewnątrz budynku.

Poniżej przedstawiono porównanie przegród budowlanych z PCM i bez PCM. Na podstawie wykresu rys.1. można stwierdzić zarówno obniżenie szczytowych wartości temperatur przegrody z PCM w stosunku do tradycyjnego rozwiązania, jak i wcześniej wspomniane przesunięcie fazowe wzrostu i spadku temperatury przegrody w porównaniu do przegrody bez PCM. 


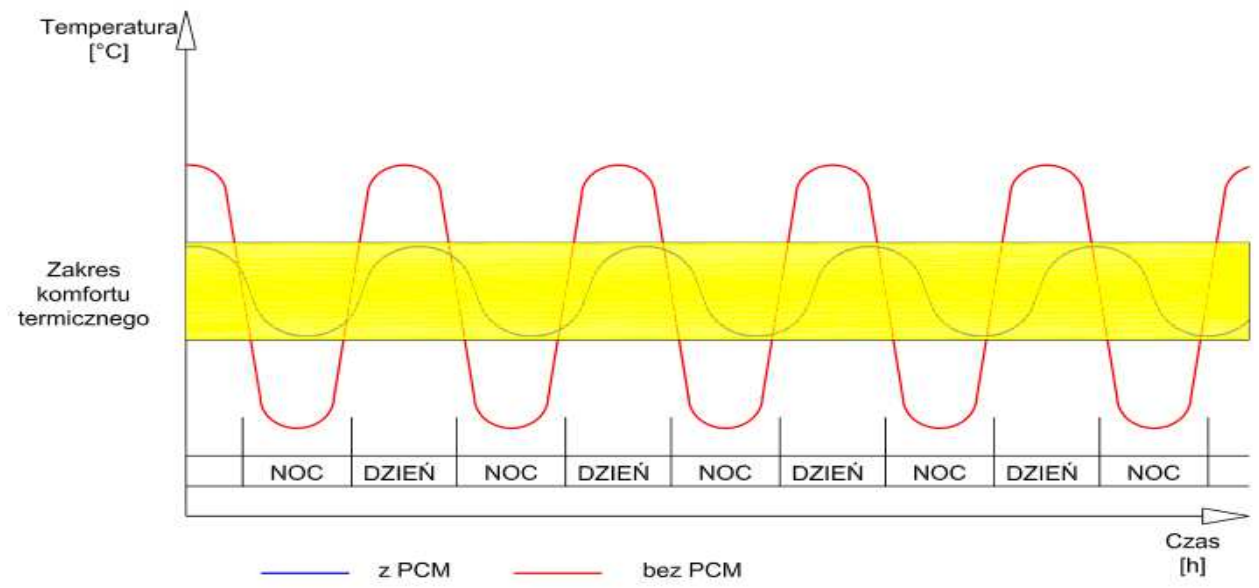

Rys. 1. Schemat ilustrujący sposób działania PCM w przegrodach budowlanych [3]

Fig. 1. Schematic showing an effect of PCMs on building barrier [3]

\section{Przykłady zastosowań PCM-ów w budownictwie}

Materiały zmiennofazowe stosowane są w budownictwie od kilkudziesięciu lat, jednak wprowadzane nowe rozwiązania wymagają usystematyzowania. Poniżej przedstawiono najczęściej spotykane przykłady zastosowań PCM-ów w przezroczystych i nieprzezroczystych przegrodach budowlanych.

W przegrodach nieprzezroczystych stosowane są następujące sposoby łączenia materiałów zmiennofazowych z tradycyjnymi materiałami budowlanymi:

- łączenie kapsułek, mikrokapsułek zawierających PCM z cementem lub gipsem [4],

- nasączanie materiałów porowatych, np. gazobeton, cegły ceramiczne,

- bezpośrednie mieszanie PCM-u z cementem lub gipsem,

- wytwarzanie stabilnych kompozytów zawierających do 80\% czystego PCMu z osnową polimerową (HDPE shape stabilized PCM),

- płyty laminowane wełną mineralną z wewnętrzną warstwą PCM-u,

- jako akumulator ciepła w postaci walców lub prostopadłościanów o wymiarach kilku - kilkunastu centymetrów pokryte powłoką polimerową, umieszczane w wolnych przestrzeniach elementów drążonych.

Bezpośrednie łączenie PCM-ów z materiałami budowlanymi jest bardzo rzadko stosowane ze względu na trudności $\mathrm{z}$ wkomponowaniem poszczególnych elementów oraz możliwość powstania korozji chemicznej. 


\section{Wybrane zastosowania PCM - ów w przegrodach przezroczystych}

Poniżej zostały przedstawione wybrane rozwiązania ukazujące zalety i wady użycia substancji zmiennofazowych we współpracy z przegrodami transparentnymi (rys. 2-5): okna, rolety (żaluzje), luksfery.

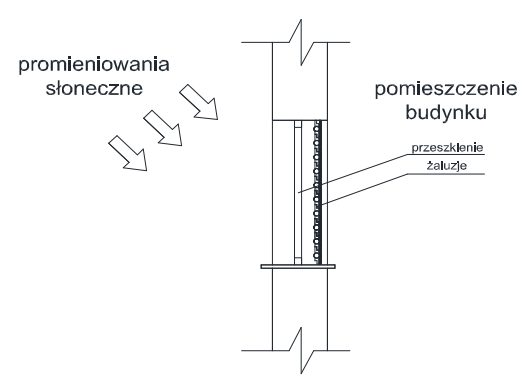

Rys. 2. Przykładowe zastosowanie PCM w żaluzjach wewnętrznych

Fig. 2. Example of PCM application in internal shutters

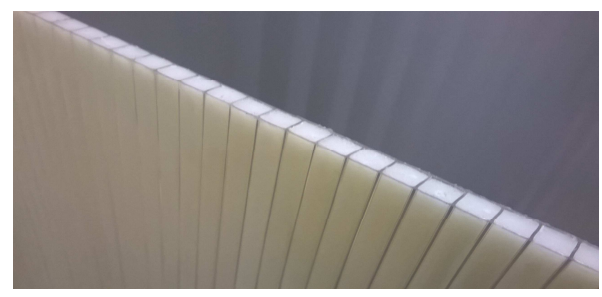

Rys. 4. Przekrój panelu poliwęglanowego z PCM

Fig. 4. Cross section of cellular polycarbonate panels with PCM

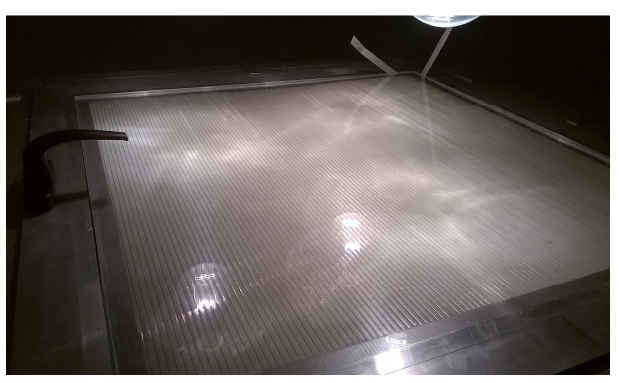

Rys. 3. Panele poliwęglanu komorowego z PCM

Fig. 3. Cellular polycarbonate panels filled with PCM

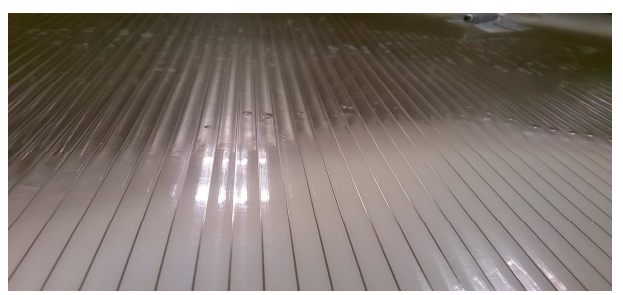

Rys. 5. Częściowo roztopiony PCM wewnątrz poliwęglanu komorowego

Fig. 5. Partially melted PCM in cellular polycarbonate

Jednym z rozwiązań, wpisujących się w powyższe założenia, są żaluzje bądź rolety, które ograniczają straty ciepła przez przegrody transparentne w miesiącach zimowych oraz zapobiegają przegrzewaniu pomieszczeń w sezonie letnim. W literaturze naukowej można spotkać się z wieloma rozwiązaniami, polegającymi na przeciwdziałaniu przepływowi ciepła z lub do wnętrza budynku przez przegrody transparentne, jednak tylko nieliczne rozwiązania zakładają wykorzystanie zmagazynowanej energii cieplej, zgromadzonej z energii promieniowania słonecznego w trakcie dnia (szczególnie w okresie przejściowym), aby zmniejszyć dobowy gradient temperatury powietrza wewnątrz budynku $[5,6,7]$. 
Opisane w [8] rozwiązanie polega na wykorzystaniu materiałów zmiennofazowych w ruchomych roletach wewnętrznych działających w systemie 24-godzinnym. System polega na cyklicznym topnieniu i zestaleniu PCMu zlokalizowanego wewnątrz listew rolet odpowiednio w dzień i w nocy w celu zmniejszenia dobowej amplitudy temperatur w pomieszczeniu oraz zwiększenia bezwładności termicznej przegrody. Badania [8] były prowadzone w Karlsruhe i Kassel w Niemczech w latach 2008-2010, a wyniki wykazały, że system jest dobrym rozwiązaniem w przypadku lekkich konstrukcji, szczególnie w zimie, gdy zwiększona bezwładność cieplna przegrody zwiększa komfort termiczny. $\mathrm{Z}$ kolei badania [8] przeprowadzone w lecie wykazały mniejszy przyrost temperatury powietrza wewnątrz pomieszczenia $\mathrm{w}$ stosunku do rolet bez PCM, co zmniejszyło szczytowe obciążenie klimatyzatorów.

Dodatkowo w $[8,9,10]$ zostały opisane możliwości wykorzystania PCM do bezpośredniej modyfikacji przeszkleń, badania były prowadzone przy użyciu modeli fizycznych i numerycznych. Na podstawie przeprowadzonych badań stwierdzono, że nawet podczas słonecznych dni miesięcy zimowych w klimacie umiarkowanym potencjał ciepła utajonego materiału fazowozmiennego był w pełni wykorzystany. Potrzebne są jednak okresy wysokiego natężenia promieniowania słonecznego przy dość wysokich temperaturach powietrza zewnętrznego.

W [11] opisano badania nad żaluzjami $\mathrm{z}$ wkomponowanym PCM w ruchomych listwach. Badania [11] zostały przeprowadzone dla dwóch przypadków: dla komory z żaluzjami z PCM wewnątrz listew oraz dla komory $\mathrm{z}$ konwencjonalnymi żaluzjami. Badania przeprowadzono w miesiącach zimowych w klimacie śródziemnomorskim. Poszczególne listwy żaluzji zostały wykonane w sposób, który zakłada umieszczenie PCM jedynie w połowie szerokości przekroju poprzecznego pojedynczej listwy.

Stosowanie PCM w żaluzjach powoduje ograniczenie przepływu ciepła przez przegrody przeźroczyste oraz zwiększa jej bezwładność termiczną, co zmniejszy dobową amplitudę temperatur. Mankamentem powyższego rozwiązania jest dobór niewłaściwego PCMu o zbyt niskiej temperaturze topnienia jak dla śródziemnomorskich danych klimatycznych.

Rozwiązaniem wykorzystującym PCM do zwiększenia bezwładności termicznej przegród oraz zmniejszenia dobowej amplitudy temperatury w pomieszczeniach budynku są również żaluzje opisane w [12].

Badania [12] zostały przeprowadzone dla Kuwejtu oraz innych krajów o klimacie gorącym. Celem powyższych badań było zminimalizowanie ilości energii potrzebnej do zasilania klimatyzatorów. Badaniom zostały poddane okiennice z zamontowanymi zewnętrznymi żaluzjami z listwami o grubości $3 \mathrm{~cm}$, w których znajduje się PCM oraz okiennice ze standardowymi żaluzjami, które są wypełnione pianką poliuretanową. Wyniki przeprowadzonych badań wykazały, że prócz wymienionych wyżej właściwości, stosowanie PCM wewnątrz zewnętrznych żaluzji w klimacie gorącym skutkuje 20-24 \% zmniejszeniem przyrostu temperatury powietrza $\mathrm{w}$ pomieszczeniu $\mathrm{w}$ stosunku do po- 
mieszczenia ze standardowymi żaluzjami. Dodatkowo należy wspomnieć, że o sprawności całego systemu będzie decydować odpowiednio dobrany PCM, którego temperatura topnienia zbliża się do maksymalnej temperatury okien w ciągu dnia (w przypadku klimatu gorącego).

Kolejne wykorzystanie PCM w przegrodach przeziernych zostało opisane w [13]. Autor przedstawił wyniki badań użycia glikolu propylenowego (organicznego PCM) wewnątrz jednokomorowego zespołu szybowego w celu zmniejszenia ilości energii przekazywanej do pomieszczeń. Badania zostały przeprowadzone przy użyciu różnych grubości szyb i warstw PCM umieszczonego między nimi. Mierzone parametry zostały porównane $\mathrm{z}$ wynikami modelu numerycznego i wskazują na dużą redukcję ilości energii przesyłanej przez komponent (w zakresie podczerwieni i ultrafioletu) przy zachowaniu dobrej przezierności. Powyższe badania odnoszą się jedynie do sytuacji przegrzewania pomieszczeń i nie odnoszą się do klimatu umiarkowanego Polski.

\section{Inne zastosowania PCM w budownictwie}

Coraz częściej materiały zmiennofazowe znajdują zastosowanie w systemach wykorzystujących energię odnawialną jako akumulator ciepła oraz pozyskują energię z systemów zysków bezpośrednich. Oto przykładowe zastosowania:

- pochłanianie nadmiaru ciepła powstałego podczas wiązania betonu [14],

- pochłanianie nadmiaru ciepła z paneli fotowoltaicznych nadmiernego wzrostu temperatury. Wzrost temperatury paneli wpływa negatywnie na ich sprawność [15],

- modyfikacja materiałami zmiennofazowymi akumulatorów ciepła (często połączone z instalacją kolektorową),

- modyfikacja ścian kolektorowo - akumulacyjnych [16],

- nasączanie ceramicznych materiałów porowatych [17, 18, 19].

$\mathrm{W}[17,18,19]$ przedstawiono zalety i wady nasączania parafiną ceramicznych materiałów porowatych. Przedstawione wyniki badań w [18] ukazują możliwość znacznego zwiększenia przewodności cieplnej kompozytu zbudowanego z pianki grafitowej nasączonej parafiną w stosunku do samej parafiny. Tak duże zwiększenie przewodności cieplnej skutkuje znacznym zwiększeniem efektywności PCM, np. w przegrodach budowlanych.

\section{Wnioski}

Wymienione przykłady zastosowań PCM-ów we współpracy z budowlanymi przegrodami przezroczystymi obrazują potencjalne zyski związane $\mathrm{z}$ obniżeniem kosztów utrzymania w pomieszczeniach pożądanego zakresu temperatur. Należy jednak zwrócić uwagę na potrzebę każdorazowego doboru PCM o odpowiedniej wartości ciepła przemiany fazowej, jak i zakresowi temperatur, w jakim powyższe zjawisko ma miejsce. 
Konieczność doboru odpowiednich PCM w zależności od ich zastosowania, rozmieszczenia oraz warunków klimatycznych, świadczy o potrzebie dedykowania grup PCM o zbliżonych właściwościach do konkretnych zastosowań.

W przedstawionych powyżej przykładach wykorzystanie substancji zmiennofazowych w przegrodach przezroczystych daje lepsze rezultaty w klimacie ciepłym, podczas próby ograniczenia przegrzania pomieszczeń niż w przypadkach dotyczących klimatu umiarkowanego, gdzie PCM ma również minimalizować koszty związane ze stratami ciepła przez w/w przegrody.

\section{Literatura}

[1] Shamberger P. J., Reid T: Thermophysical Properties of Potassium Fluoride Tetrahydrate from (243 to 348) K, Jurnal of chemical \& engineering data 2013, 58, 294-300.

[2]Jaworski M: Materiały zmiennofazowe ( $\mathrm{pcm}$ ) w budownictwie - właściwości i rodzaje, www.izolacje.com.

[3]Musiał M: Zastosowania materiałów zmiennofazowych (PCM) w budownictwie, s.42-45, 2015 Dom Wydawniczy Medium, Izolacje, Z.(195).

[4]Heim D: Efektywna Głębokość Wnikania Ciepła W Przegrodzie Pełnej Wypełnionej Mfz, Budownictwo I Inżynieria Środowiska Zeszyt 58 Nr3/2011/3 Rzeszów 2011.

[5]Lichołai L., Musiał M: Wpływ organicznych materiałów zmiennofazowych na efektywność energetyczną przegrody przezroczystej, Czasopismo Inżynierii Lądowej, Srodowiska i Architektury - Journal of Civil Engineering, Environment and Architecture, JCEEA, t. XXXIII, z. 63 (4/16), 2016, s. 329-338, DOI:10.7862/rb.2016.277.

[6]Musiał M., Kaczmarzyk M: Thermal properties of transparent Barrier modified witch organic PCMs, Czasopismo Inżynierii Lądowej, Środowiska i Architektury - Journal of Civil Engineering, Environment and Architecture, JCEEA t. XXXIII 63 (2/I/2016), 2016, s. 171-178, DOI:10.7862/rb.2016.15.

[7]Heim D., Janicki M:Wpływ doboru typowych rozwiązań przegród transparentnych na zyski ciepła przez fasadę podwójną, Budownictwo i Inżynieria Środowiska Kwartalnik z. 58, 3/2011/III Rzeszów 2011.

[8] Soares N, Costa J.J, Gaspar A. R, Santos P:Review of passive PCM latent heat thermal energy storage systems towards buildings' energy efficiency, Energy and Buildings Volume 59, April 2013, Pages 82-103.

[9] Grynning S, Goia F, Rognvik E, Time B: Possibilities for characterization of a PCM window system using large scale measurements, International Journal of Sustainable Built Environment Volume 2, Issue 1, June 2013, Pages 56-64.

[10] Kamal A.R. Ismail, Carlos T. Salinas, Henriquez J.R: Comparison between PCM filled glass windows and absorbing gas filled window, Energy and BuildingsVolume 40, Issue 5, 2008, Pages 710-719.

[11] Silva T, Vicente R, Rodrigues F, Samagaio A, Cardoso C: Development of a Window Shutter with Phase Change Materials: full scale outdoor Experimental Approach, Energy And Buildings Volume 88, 1 February 2015, Pages 110-121.

[12] Esam M. Alawadhi E. M: Using Phase Change Materials In Window Shutter To Reduce The Solar Heat Gain, Energy And Buildings Volume 47, April 2012, Pages 421-429. 
[13] Ismail K. A. R, Henriequez J. R „Pcm Glazing Systems” International Journal Of Energy Research, Vol. 21, 1241-1255 (1997).

[14] Hsino M., Pasławski J: Materiały zmiennofazowe jako modyfikator betonu dojrzewającego w klimacie gorącym i suchym, www.izolacje.com.

[15] Kuhn T. E: Solar Control: A General Evaluation Method For Facades With Venetian Blinds Or Other Solar Control Systems, Energy And Buildingsvolume 38, Issue 6, June 2006, Pages 648-660.

[16] Lichołai L., Krasoń J: Badania laboratoryjne cieplnego funkcjonowania przegród kolektorowo-akumulacyjnych modyfikowanych materiałem zmienno-fazowym, Fizyka budowli w teorii i praktyce. tom VII, nr 2 2015, s. 39-44.

[17] Xiangfa Z., Hanning X., Feng J., Changrui Z., Yonggang J: Preparation and thermal properties of paraffin/porous silica ceramic composite, Composites Science and Technology 69 (2009) 1246-1249.

[18] Xiangfa Z., Hanning X., Feng J., Changrui Z., Yonggang J: Pore structure modification of silica matrix infiltrated with paraffin as phase change material, Chemical Engineering Research and Design 88 (2010) 1013-1017.

[19] Yajuan Z., Quangui G., Sizhong L., Jingli S., Lang L: Heat transfer enhancement of paraffin wax using graphite foam for thermal energy storage, Solar Energy Materials \& Solar Cells 94 (2010) 1011-1014.

\section{APPLICATION OF PHASE CHANGE MATERIALS ON TRANSPARENT BARRIERS}

\section{S u m m a r y}

This paper is a review of contemporary research and actual applications of phase change materials (PCM) on transparent barriers. It was found necessary to systemize actual knowledge concerning the subject, as new applications of PCMs on transparent barriers are developed.

The paper describes basic properties of phase change materials, that justify their increasingly often use in civil engineering. Already existing products augmented with PCMs are presented here along with results of the most recent research conducted on innovative solutions that have never been tested before. Author refers to other works, that describe various solutions, that use PCMs in order to increase thermal inertia of building barriers. Applications of phase change materials on either transparent and opaque building barriers were presented.

Authors of the Papers that elaborate on advantages and disadvantages of using phase change materials with transparent barriers, focus mostly on an ability of PCMs to increase thermal inertia of a barrier, that makes it less susceptible for external temperature and solar irradiance changes. Author emphasizes importance of such material properties as melting point, volumetric thermal expansion and thermal conductivity, as well as reversibility of melting/solidifying cycles. Additionally, it is vital to determine, whether PCM is to serve as overheating or overcooling protection, as the function influences exact way of application and location of phase change material.

Mentioned factors have considerable impact on effectiveness of described solutions.

The fact, that the majority of the works concerning PCMs applications in civil engineering is dedicated to opaque building barriers, points out an innovative character of this work.

Keywords: phase change materials, transparent barriers, modifications of building barriers

Przestano do redakcji: 24.02 .2017 r.

Przyjęto do druku: 31.03.2017 r. 